\title{
Study of role of blood transfusion in obstetric emergencies
}

\author{
Vibhuti Pravinbhai Patel, Rina V. Patel*, Parul T. Shah, Chirag K. Patel
}

Department of Obstetrics \& Gynaecology, Smt N H L Municipal Medical College, Sheth V S General Hospital, Ahmedabad-380009, Gujarat, India

Received: 23 September 2014

Accepted: 22 October 2014

*Correspondence:

Dr. Rina V. Patel,

E-mail: rinaviral1975@gmail.com

Copyright: (C) the author(s), publisher and licensee Medip Academy. This is an open-access article distributed under the terms of the Creative Commons Attribution Non-Commercial License, which permits unrestricted non-commercial use, distribution, and reproduction in any medium, provided the original work is properly cited.

\begin{abstract}
Background: Blood Transfusion is recognized as one of the eight essential component of comprehensive emergency obstetric care which has been shown to reduce the maternal mortality. ${ }^{1,2}$ In developing country like India, efforts should be done to make blood and transfusion services well maintained and quickly available to reduce maternal morbidity from haemorrhage and thus decrease the incidence of maternal mortality. Aims \& objectives: (1) To study clinical status of the patients at time of admission. (2) To study the role of antenatal visits in all patients required blood transfusion. (3) To study the effect of blood components on the patients' health. (4) To screen out the patients of high risk pregnancy and treat them safely. (5) To study causes of maternal mortality.

Methods: Retrospective study of requirement of blood transfusion in antenatal and postnatal patients who came in labour room during last 3 month period at tertiary care Centre, Ahmedabad.

Results: during the whole study out of 2200 patients 440 patients required blood transfusion among which $70 \%$ required due to obstetric hemorrhage and $30 \%$ due to severe anemia (less than $7 \mathrm{gm} / \mathrm{dl}$ ). Major associated complications in the transfused patients were anemia (34\%) and PPH (36\%). 4 patients expired among them 2 were due to development of DIC and septicemia, 1 due to severe anemia and 1 due to severe PPH.

Conclusions: Ensuring a safe supply of blood and blood products and the appropriate and rational clinical use of blood. Strategies made to maximize the haemoglobin $(\mathrm{Hb})$ level at the time of delivery as well as to minimize blood loss. Active management of the third stage of labour is required to prevent avoidable morbidities, such as PPH, Retained product of conception, and vaginal lacerations.
\end{abstract}

Keywords: Blood transfusion, Pregnancy, Preeclampsia, Septicemia

\section{INTRODUCTION}

In India, direct cause of maternal mortality still remains hemorrhage. Preeclampsia, sepsis, with anemia being the most common indirect cause.

WHO has estimated that prevalence of anemia in developed and developing countries in pregnant women is 14 per cent and 51 per cent respectively. In India the prevalence of anemia is around 65-75 percent. ${ }^{3} \mathrm{PPH}$ is the most common cause of maternal morbidity in developing county like India and is a major cause of death.

Globally about $11 \%$ of women having live births have severe PPH amounting to 14 million women a year. ${ }^{4}$ The incidence of $\mathrm{PPH}$ is said to be $3.9 \%$ in vaginal deliveries $\& 6.4 \%$ in cesarean deliveries. ${ }^{5}$

In India alone, according to a review of the sample registration survey (1997-2003), postpartum hemorrhage accounts for nearly $38 \%$ of all maternal deaths. ${ }^{6}$ 
Access to a safe and sufficient blood supply could help to prevent deaths of a significant number of mothers and their newborn children. India contributes to about $20 \%$ of maternal mortality in the world. Blood transfusion is associated with complications like allergic reactions (fever, anxiety, breathlessness, tachycardia, hypotension, and chest pain), acute immune hemolytic reaction, delayed hemolytic reaction, risk of transmission of viruses and infectious disease (HIV, hepatitis B \& C).

Every year, millions of people are exposed to avoidable, life-threatening risks through the transfusion of unsafe blood. The first referral units were should be fully operational with expert specialist staff, infrastructure, equipment, medicines, and blood-transfusion facilities which can reduce maternal mortality. ${ }^{7}$

\section{METHODS}

Retrospective study of requirement of blood transfusion in antenatal and postnatal patients (emergency or registered) who came in labour room during last 3 months period was conducted at tertiary care unit, Ahmedabad. All antenatal and postnatal patients within peripartum period were taken.

Inclusion criteria: 1) All delivered or undelivered emergency and registered patients who came in labour room. 2) All patients requiring blood transfusion in antepartum, intrapartum and postpartum period were selected. 3) Severe anemic patients with $\mathrm{Hb}$ level less than $7 \mathrm{gm} / \mathrm{dl}$ were selected. 4) Postpartum patients with more than $1000 \mathrm{ml}$ of blood loss were included.

\section{RESULTS}

Out of 2200 patients 440 patients required blood transfusion.

Table 1: Patients requiring blood transfusion.

\begin{tabular}{|lll|}
\hline Cause & $\begin{array}{l}\text { No. of } \\
\text { patients }\end{array}$ & Percentage \\
\hline Obstetric haemorrhage & 308 & $70 \%$ \\
\hline Anaemia & 132 & $30 \%$ \\
\hline
\end{tabular}

In this study $70 \%$ patients required blood transfusion because of obstetric haemorrhage and 30\% patients required blood because of anemia of pregnancy.

Table 2: Total blood and blood products given to the patients.

\begin{tabular}{|ll|l|}
\hline Type of transfusion & $\begin{array}{l}\text { No. of } \\
\text { patients }\end{array}$ & Percentage \\
\hline Only PCV & 332 & $80 \%$ \\
\hline $\begin{array}{l}\text { PCV + blood components } \\
\text { (FFP, PRC, Cryoprecipitate) }\end{array}$ & 88 & $20 \%$ \\
\hline
\end{tabular}

During this study $80 \%$ patients were transfused with PCV only and $20 \%$ patients received combination of blood and blood products like FFP, PRC, and Cryoprecipitate.

Table 3: Blood transfusion in according to hemoglobin level.

\begin{tabular}{|lll|}
\hline Hb $(\mathrm{gm} / \mathrm{dl})$ & $\begin{array}{l}\text { No. of } \\
\text { patients }\end{array}$ & Percentage \\
\hline$<7$ & 233 & $53 \%$ \\
\hline $7-9.9$ & 141 & $32 \%$ \\
\hline $10-10.9$ & 66 & $15 \%$ \\
\hline
\end{tabular}

$53 \%$ of patients with $\mathrm{Hb}$ less than $7 \mathrm{gm} / \mathrm{dl}$ required blood transfusion in present study.

Table 4: Associated complication which requiring blood and blood products.

\begin{tabular}{|lll|}
\hline Complications & $\begin{array}{l}\text { No. of } \\
\text { patients }\end{array}$ & Percentage \\
\hline First trimester bleeding & 30 & $7 \%$ \\
\hline Anaemia & 150 & $34 \%$ \\
\hline Preeclampsia & 53 & $12 \%$ \\
\hline Abruptio placenta & 22 & $5 \%$ \\
\hline Medical condition (fever, jaundice) & 9 & $2 \%$ \\
\hline Post-partum haemorrhage & 158 & $36 \%$ \\
\hline DIC & 18 & $4 \%$ \\
\hline
\end{tabular}

Major associated complications in the transfused patients were anemia (34\%) and PPH (36\%).

Table 5: Fetal outcome.

\begin{tabular}{|lll|}
\hline Fetal outcome & $\begin{array}{l}\text { No. of } \\
\text { babies }\end{array}$ & Percentage \\
\hline Live & 360 & $82 \%$ \\
\hline Intra uterine death & 53 & $12 \%$ \\
\hline Neonatal death & 27 & $6 \%$ \\
\hline
\end{tabular}

In this study $82 \%$ babies were live, $12 \%$ babies were IUD and $6 \%$ babies were died in neonatal period.

Table 6: Maternal mortality.

\begin{tabular}{|lll|} 
Causes & $\begin{array}{l}\text { No. of } \\
\text { patients }\end{array}$ & $\begin{array}{l}\text { Emergency } \\
\text { / registered }\end{array}$ \\
\hline Severe anaemia & 1 & Emergency \\
\hline PPH & 1 & Registered \\
\hline DIC & 2 & Emergency \\
\hline
\end{tabular}

Out of 440 patients maternal mortality occur in 4 patients.

In this study one maternal death was occurred in multiparous vaginaly delivered woman having severe atonic PPH with poor general condition. 
One patient of $2 \mathrm{gm} / \mathrm{dl} \mathrm{Hb}$ was referred from outside died immediately after delivery due to cardiac arrest.

Two patients required many blood transfusions and blood products like FFP and PRC and developed DIC and septicemia and expired due to acute renal failure.

\section{DISCUSSION}

Because of the unpredictable nature of postpartum bleeding, blood transfusion has been identified as one of eight essential key that should be available in healthcare facilities providing comprehensive emergency obstetric care. $^{1,2}$

In developing country two main causes of maternal mortality and morbidity regarding blood transfusion in obstetric are;

\section{Anemia of pregnancy}

2. Major obstetric haemorrhage

Anemia of pregnancy is defined as haemoglobin concentration below $11 \mathrm{gm} / \mathrm{dl}$ in first and third trimester and below $10.5 \mathrm{gm} / \mathrm{dl}$ in second trimester. Anemia is a late manifestation of iron deficiency; transfusion does not treat the cause of anemia. Preexisting anemia worsens as pregnancy advances, leading to $\mathrm{CHF}$ and other complication including mortality of the patient. It also impedes the patient's ability to resist infection or cop up with haemorrhage.

The decision of blood transfusion should be made on both clinical and hematological grounds. Transfusion is almost always indicated when $\mathrm{Hb}$ is less than $7 \mathrm{gm} / \mathrm{dl}^{9,10}$ to reduce the rate of maternal morbidity and mortality.

Obstetric haemorrhage is defined as any blood loss occurring in the peripartum period may be revealed or concealed, that is likely to endanger life. Haemorrhage is associated with $48 \%$ of direct cause of obstetric death and $38 \%$ of all maternal death. Most common obstetric emergencies in developing countries are $\mathrm{PPH}, \mathrm{APH}$, ruptured uterus, eclampsia, obstructed labour and infection.

More active participation in term of antenatal checkups and skilled management of patients at the first referral unit is advocated.

During my study blood transfusion is mainly indicated to restore red cell count in order to improve the ability of blood to transport oxygen and to prevent tissue and organ hypoxia, replacement of clotting factors, replacement of vascular volume. Blood component therapy is mainly administered to treat specific conditions like micro vascular bleeding, and coagulation factor deficiency.

Haemorrhage is extremely unpredictable so volume replacement done with up to 2 liters of crystalloid. Plasma expanders should follow until the blood is available. ${ }^{15}$ In a case of acute bleeding, PRC was given to maintain platelet count at $\geq 50 \times 109 /$ L. Fresh frozen plasma is used for correction of hypovolemia and normalization of coagulation in a case. When DIC is strongly suspected and clotting studies take a long time, transfusion of FFP was given before result are available if haemorrhage is otherwise difficult to control.

On one side maternal morbidity and mortality depends on availability of blood and blood products, on the other side injudicious use of blood and blood products can cause infection, allergic reaction or antibody production in the mother which can have major impact on the present or future pregnancies. ${ }^{11}$

According to the World Health Organization (WHO), the four cornerstones of a safe and effective blood donor service are a national system, volunteer donations, blood testing, and avoidance of unnecessary transfusions. ${ }^{12}$ each of these cornerstones poses challenges in developing countries, where infrastructure may be limited; the cost of blood procurement, screening, and storage is high; and blood donation is rare. In $2002,5 \%$ to $10 \%$ of newly acquired HIV infections were related to infected blood transfusions. ${ }^{13}$ as women and children are the most likely recipients of blood in areas of both high HIV prevalence and blood supply shortages, they are at disproportionately high risk. ${ }^{14}$

Main purpose of this study is to make the blood available in the blood bank and should be reserved for the patients of the obstetric emergencies. Blood should be reserved for the patients of severe anemia, patients having any type of bleeding in antenatal and postnatal period.

In developing countries an understanding of public health determinants is integral to the success of any intervention to reduce maternal mortality, in addition to an understanding of the biomedical causes and management of obstetric hemorrhage. Alternatives to banked blood include autologous blood donation, normovolemic haemodilusion, and intraoperative cell salvage. These should be considered in patients who are difficult to cross match and/or who refused banked blood.

\section{CONCLUSION}

Ensuring a safe supply of blood and blood products and the appropriate and rational clinical use of blood are important public-health responsibilities of every national and state government, especially for saving lives of mothers who need comprehensive emergency obstetric care services because of pregnancy-related haemorrhage, severe anaemia, or abortions. Strategies to be make to maximize the haemoglobin $(\mathrm{Hb})$ level at delivery as well as to minimize blood loss. Particular emphasis should be placed on the management of the third stage of labour, to prevent avoidable morbidities, such as $\mathrm{PPH}$, retained product of conception, and vaginal lacerations, which require transfusions. Until adequate national blood banks are in place, we should continue to explore alternatives to 
allogenic blood transfusion for obstetric and gynecologic haemorrhage.

\section{ACKNOWLEDGEMENTS}

Authors would like to thank Dr. S. T. Malhan, the Superintendent of Sheth V. S. General Hospital, and Dr. Pankaj R. Patel, the Dean of Smt N. H. L. Municipal Medical College to allow us to publish this paper.

Funding: No funding sources

Conflict of interest: None declared

Ethical approval: The study was approved by the institutional ethics committee

\section{REFERENCES}

1. Chandy BK. WHO fact sheet. Kuwait Med J. 2007;39(3):298-302.

2. Cruz JR. Reduction of maternal mortality: the need for voluntary blood donors. Int J Gynaecol Obstet. 2007;98:291-3.

3. DeMayer EM, Tegman A. Prevalence of anaemia in the world. World Health Organ Qlty. 1998;38:30216.

4. Parikh MN. Introduction of postpartum haemorrhage. Fogsifocus. 2007;11:1-2. RCOG. Blood transfusion in obstetrics, RCOG Green top guideline no. 47, 2007. Available at: https://www.rcog.org.uk/globalassets/documents/gui delines/gt47bloodtransfusions1207amended.pdf.

5. Cunningham FG, Norman FG, Kenneth JL, Gilstrap LC, Hauth JC, Wenstrom KD, et al. Postpartum haemorrhage. In: editors: F. Gary, eds. Williams Obstetrics. 1st ed. New York: McGraw Hill: 2001.

6. Registrar General of India. Sample registration survey. Maternal mortality in India: 1997-2003, trends, causes and risk factors. In: Registrar General of India, eds. A Survey. New Delhi: Registrar General of India; 2006: 29.

7. SahayogIndia. Fact sheet: maternal mortality and morbidity, 2008. Available at: http://www.sahayogindia.org/what's\%20new/fact_ sheet\%20on\%20MMM.pdf. Accessed 3 June 2008.

8. The Hindu. Blood storage centers to reduce maternal mortality, 2007. Available at: http: //www.thehindu. com/2007/10/13/stories/2007101359870100.htm.

9. British Committee for Standards in Haematology, Blood Transfusion Task Force. Guidelines for the clinical use of red cell transfusions. Br J Haematol. 2001;113:24-31.

10. United Kingdom Blood Services. Blood transfusion. In: McClelland DBL, eds. Handbook of Transfusion Medicine. 3rd ed. London: The Stationery Office; 2001.

11. RCOG. Blood transfusion in obstetrics, RCOG Green top guideline no. 47, 2007. Available at: https://www.rcog.org.uk/globalassets/documents/gui delines/gt47bloodtransfusions 1207amended.pdf.

12. World Health Organization (WHO). Essential health technologies. Blood transfusion safety, 2011. Available at: http://www.who.int/ bloodsafety/en/Blood_Transfusion_Safety.pdf. Accessed 14 June 2011.

13. World Health Organization (WHO). Blood Safety: aide-memoire for national programmes, 2002. Available at: http://www.who.int/bloodsafety/transfusion_services/en/Blood_Safety_En g.pdf. Accessed 14 June 2011.

14. Dhingra N. Making safe blood available in Africa, 2006. Available at: http://www.who.int/bloodsafety/makingsafe bloodavailableinafricastatement.pdf. Accessed 14 June 2011.

15. Kate Grady, Charlott Howell, Charles Cox. Haemorrhage. In: Kate Grady, Charlott Howell, Charles Cox, eds. The MOET course Manual. 2nd ed. London: Royal College of Obstetricians and Gynaecologists; 2007:174-5.

DOI: $10.5455 / 2320-1770 . i j r \operatorname{cog} 20141225$

Cite this article as: Patel VP, Patel RV, Shah PT, Patel CK. Study of role of blood transfusion in obstetric emergencies. Int J Reprod Contracept Obstet Gynecol 2014;3:1002-5. 